\title{
Among-species variation in the energy budgets of reef-building corals: scaling from coral polyps to communities
}

\author{
Mia Hoogenboom ${ }^{1, *}$, Cécile Rottier ${ }^{2}$, Severine Sikorski ${ }^{2}$ and Christine Ferrier-Pagès ${ }^{2}$
}

\begin{abstract}
The symbiosis between corals and dinoflagellates promotes the rapid growth of corals in shallow tropical oceans, and the high overall productivity of coral reefs. The aim of this study was to quantify and understand variation in carbon acquisition and allocation among coral species. We measured multiple physiological traits (including symbiont density, calcification, photosynthesis and tissue composition) for the same coral fragments to facilitate direct comparisons between species (Stylophora pistillata, Pocillopora damicornis, Galaxea fascicularis, Turbinaria reniformis and Acropora sp.). Tissue protein content was highly sensitive to the availability of particulate food, increasing in fed colonies of all species. Despite among-species variation in physiology, and consistent effects of feeding on some traits, overall energy allocation to tissue compared with skeleton growth did not depend on food availability. Extrapolating from our results, estimated whole-assemblage carbon uptake varied $>20$-fold across different coral assemblages, but this variation was largely driven by differences in the tissue surface area of different colony morphologies, rather than by differences in surface-area-specific physiological rates. Our results caution against drawing conclusions about reef productivity based solely on physiological rates measured per unit tissue surface area. Understanding the causes and consequences of among-species variation in physiological energetics provides insight into the mechanisms that underlie the fluxes of organic matter within reefs, and between reefs and the open ocean.
\end{abstract}

KEY WORDS: Energy balance, Heterotrophic feeding, Lipid stores, Stable isotope analyses, Photosynthesis, Scleractinian corals

\section{INTRODUCTION}

Nutritional symbioses promote efficient recycling of nutrients in terrestrial, aquatic and marine ecosystems, and involve numerous host and symbiont taxa (Saffo, 1992). One of the most widely recognised nutritional symbioses is that between corals and photosynthetic dinoflagellates from the genus Symbiodinium (zooxanthellae). This symbiosis augments the carbon supply to the coral while the symbionts benefit from nutrient supply, and the relatively stable endocellular environment, provided by the coral host (Yellowlees et al., 2008). Additionally, recent studies have revealed nutrient exchange between corals and the microbial community living within the tissue surface layer (Kushmaro and Kramarsky-Winter, 2004; Garren and Azam, 2012), as well as between corals and endolithic algae colonising the space between

\footnotetext{
${ }^{1}$ College of Marine and Environmental Sciences and ARC Centre of Excellence for Coral Reef Studies, James Cook University, Townsville, Queensland 4811 Australia. ${ }^{2}$ Centre Scientifique de Monaco, 8 Quai Antoine 1er, MC98000, Monaco.

*Author for correspondence (mia.hoogenboom1@jcu.edu.au)
}

Received 27 April 2015; Accepted 8 October 2015 coral tissue and skeleton (Fine and Loya, 2002). Overall, coral symbioses are characterised by complex sharing involving nitrogen (Reynaud et al., 2009; Tanaka et al., 2015) and carbon (Hughes et al., 2010; Hughes and Grottoli, 2013) that promotes the high overall productivity of coral reefs.

In addition to obtaining carbon from symbiont photosynthesis, coral polyps acquire carbon and nutrients through heterotrophic feeding on a variety of sources including zooplankton (e.g. Sebens et al., 1996; Ferrier-Pagès et al., 2003; Palardy et al., 2005), picoand nano-plankton (Bak et al., 1998; Houlbrèque et al., 2004; Ribes et al., 2003), suspended particulate matter (e.g. Anthony, 1999; Mills et al., 2004) and dissolved organic compounds (e.g. Ferrier, 1991; Grover et al., 2008; Godinot et al., 2011). Early studies on tropical corals suggested that coral reefs were 'oases' in the oligotrophic tropical seas and functioned as closed systems with limited exchange of nutrients with the surrounding sea (Odum and Odum, 1955; Johannes et al., 1972). However, an alternative view at that time was that heterotrophy provided an important source of nitrogen and phosphorus but contributed little carbon to coral symbioses (Johannes et al., 1970; Muscatine and Porter, 1977). In contrast, recent work indicates that heterotrophy contributes $70-100 \%$ of daily carbon requirements (Houlbrèque and FerrierPagès, 2008; Grottoli et al., 2006). Moreover, some coral species upregulate heterotrophic feeding when photosynthesis is suppressed, either due to decreased light availability (Anthony and Fabricius, 2000; Tremblay et al., 2015), or when symbionts are lost from coral tissue (Palardy et al., 2008 and Grottoli et al., 2014). Given that heterotrophic feeding can contribute up to $150 \%$ of $\mathrm{C}$ requirements, understanding how changing environmental conditions are likely to influence the productivity of coral communities requires knowledge of plankton and particulate matter abundance, and of the rates of particulate matter uptake by corals.

Particulate matter and dissolved nutrients can be present at high concentrations in coral reef waters. Although daytime standing stocks of zooplankton can be very low (see Heidelberg et al., 2004), shortly before sunset demersal zooplankton begin to rise into the water column and reach concentrations up to $\sim 10 \mathrm{mg} \mathrm{m}^{-3}$ (Yahel et al., 2005; Heidelberg et al., 2004). Moreover, hydrodynamic features such as upwellings and internal waves can lead to large increases in plankton densities in shallow waters (Leichter et al., 1998; Roder et al., 2010). Similarly, strong currents can interact with benthic topography to concentrate plankton from a large volume of water into a comparatively small area, greatly amplifying local zooplankton densities (Genin, 2004). Even when nutrients are in low concentrations in open waters, the dissipation of energy as waves impinge onto topographically complex reefs drives high dissolved nutrient uptake rates by benthic organisms (Hearn et al., 2001). Finally, in inshore habitats, concentrations of nutrient-rich sediments can be up to $12 \mu \mathrm{mol} 1^{-1} \mathrm{NO}_{3}$ and $2 \mathrm{~mol} \mathrm{l}^{-1} \mathrm{PO}_{4}$ (Devlin and Brodie, 2005). Collectively, these studies highlight the potential 
for high local concentrations of nutrient-rich particulate matter in some reef environments.

In addition to variation in particulate matter uptake due to fluctuations in availability in the ocean, the magnitude of particulate carbon uptake by reefs is likely to be influenced by the species composition of the benthic community. Consistent with this hypothesis, the few studies that have directly quantified the contribution of particulate food to reef ecosystems (i.e. benthicpelagic coupling) have revealed 25 -fold variation in uptake rates. Early work in the Caribbean indicated a removal of $34 \%$ (by volume) of particulate matter from the water column by benthic reef organisms (Glynn, 1973), where baseline levels of particulate matter ranged between 1 and $4 \mathrm{mg} \mathrm{N} \mathrm{m}^{-3}$ (equivalent to $\sim 10 \mathrm{mg} \mathrm{m}^{-3}$ of organic matter). Other studies have shown changes in the abundances of different plankton groups between the open water and reef flat that summed to an uptake rate of $\sim 0.1 \mathrm{~g} \mathrm{C} \mathrm{m}^{-2}$ day $^{-1}$ (e.g. Ayukai, 1995), and import of carbon from ocean to reef of $\sim 0.2 \mathrm{~g} \mathrm{C} \mathrm{m}^{-2}$ day $^{-1}$ due to the activity of suspension feeding sponges, bivalves and tunicates (Genin et al., 2009). In coral dominated areas, net import of particulate carbon from ocean to reef has been estimated at $\sim 2.5 \mathrm{~g} \mathrm{C} \mathrm{m}^{-2}$ day $^{-1}$ (Fabricius and Dommisse, 2000). Variation in uptake rates between locations is likely to be partly due to spatial variation in plankton availability; for instance, a recent study reported that plankton biomass ranged from 1.0 to $15.6 \mathrm{mg} \mathrm{C} \mathrm{m}^{3}$ on Jamaican reefs (Heidelberg et al., 2004). However, additional research is required to quantify how different assemblages of reef benthic organisms vary in their reliance on externally supplied carbon.

Determining the effect of plankton feeding on coral growth additionally requires knowledge of how heterotrophic carbon is allocated to tissue biomass versus skeletal growth. To date, studies into the role of heterotrophic feeding on coral energetics have revealed species-specific effects. For instance, experimentally starved colonies of Galaxea fascicularis had the same lipid content as fed colonies, whereas starved Stylophora pistillata had approximately 50\% lower lipid content than fed colonies (Borell et al., 2008). However, detailed analysis of whether and how heterotrophic feeding influences the energy budgets of different coral species is confounded by differences among published studies in terms of species selection, environmental conditions and measuring techniques. The aims of the present study were to quantify variation in carbon acquisition and allocation among coral species, and in response to food availability, and to determine whether energy allocation to tissue compared with skeletal growth is fixed or plastic in response to changes in food availability. In addition, we aimed to resolve whether and how heterotrophic feeding alters the sharing of carbon and nitrogen between coral host and symbionts by analysing differences in the isotopic composition of symbionts compared with coral tissue. Finally, we extrapolated our results to assess whether and how coral species composition influences the uptake of particulate matter from the water column. We measured multiple physiological traits for the same coral fragments to facilitate direct comparisons within and among species. Understanding the causes and consequences of amongspecies variation in physiological energetics provides insight into the mechanisms that underlie variation in the fluxes of organic matter within reefs, and between reefs and the open ocean.

\section{MATERIALS AND METHODS}

\section{Study species and experimental treatments}

Five coral species that are generally abundant on coral reefs were compared: Stylophora pistillata (Pocilloporidae), Pocillopora damicornis
(Pocilloporidae), Galaxea fascicularis (Euphylliidae), Turbinaria reniformis (Dendrophyllidae) and Acropora sp. (Acroporidae) [where family-level taxonomic classification follows Budd et al. (2012)]. Six genetically distinct coral colonies per species were originally sourced from the Red Sea and maintained for several months under culture conditions at the Centre Scientifique de Monaco (temperature $26 \pm 0.2^{\circ} \mathrm{C}$, light $150 \mu \mathrm{mol}$ photons $\mathrm{m}^{-2} \mathrm{~s}^{-1}$ using metal halide lights on a $12 \mathrm{~h}: 12 \mathrm{~h}$ light:dark cycle). Temperature was maintained using thermostat-regulated aquarium heaters (Visy-Therm, $300 \mathrm{~W}$ ). A total of 36 small experimental colonies (nubbins, surface area 5 to $8 \mathrm{~cm}^{2}$ ) per species, 6 nubbins from each parent colonies, were created prior to the experiment, evenly distributed into 6 glass aquaria (20 litre volume) and allowed to recover for 4 weeks. During the recovery period, nubbins were not provided with food in order to remove any previous feeding effect on their physiology (see Shick et al., 2005). During the experimental period ( 5 weeks), nubbins in three of the six tanks (18 per species) were provided with Artemia salina nauplii three times a week (feeding density of approximately 2000 prey per nubbin per feeding event) whereas nubbins in the remaining three tanks (18 per species) received no food at all. After 5 weeks incubation under fed and unfed conditions, the 18 nubbins per treatment and species were divided as follows: 6 nubbins for the feeding rate measurements and the lipid determination; 6 nubbins for measurement of photosynthesis/respiration and symbiont, chlorophyll and protein concentrations; and 6 nubbins for the growth rate measurements and the $\partial^{13} \mathrm{C}$ and $\partial^{15} \mathrm{~N}$ isotopic signature of the tissue.

\section{Heterotrophic feeding rates}

Nubbins were individually placed in a 2 litre Plexiglas ${ }^{\circledR}$ flow chamber (Ferrier-Pagès et al., 2011), allowed to acclimate for $30 \mathrm{~min}$ until their tentacles were fully expanded, and then incubated in the dark with an initial concentration of $\sim 2000$ Artemia nauplii per chamber. A control tank without a coral nubbin was also included to account for natural mortality of nauplii during these incubations. Feeding rate was determined from the change in Artemia concentration during the incubation, with samples taken from each chamber at the beginning and the end of the incubation and counted using a binocular microscope. Feeding rates were normalized per unit nubbin surface area as determined using the foil-wrapping technique (Marsh, 1970)

\section{Photosynthesis and respiration}

Rates of photosynthesis and respiration were measured using a set of six temperature-controlled respirometry chambers $(50 \mathrm{ml}$ volume $)$ coupled with a Strathkelvin oxygen electrode system (Strathkelvin $928 \mathrm{~m}$ with computer interface). Electrodes were calibrated using $\mathrm{N}_{2}$ and air-bubbled seawater as $0 \%$ and $100 \%$ oxygen saturation values, respectively. Respiration was measured during incubation in darkness (30 min). Subsequently, light intensity was increased stepwise to $150 \mu \mathrm{mol}$ photons $\mathrm{m}^{-2} \mathrm{~s}^{-1}$ and then $300 \mu \mathrm{mol}$ photons $\mathrm{m}^{-2} \mathrm{~s}^{-1}$, and photosynthesis rates were measured at each light level during a $15-\mathrm{min}$ incubation. Two light levels were used to ensure that photosynthesis had reached saturation (to estimate maximum photosynthesis rates) and feeding and species effects were consistent regardless of which light level was analysed. Rates were normalized to skeletal surface area as determined by foil wrapping (see above).

\section{Skeleton growth and coral tissue and symbiont properties}

Nubbins were weighed using the buoyant weight technique (Davies, 1989) at the beginning and end of the experiment. From these weights, growth was calculated as the total weight increase over the experimental period and was not normalized to surface area or initial nubbin size. Skeletal micro-density was determined from the difference in dry and water-saturated buoyant weight of skeleton samples of each species after Bucher et al. (1998). Microdensity measurements were subsequently converted to bulk density assuming porosity of 58\% for Acropora (Bucher et al., 1998) and 60\% for Turbinaria (based on values for its close relative Leptopsammia, Caroselli et al., 2011). Bulk skeletal density estimates for Pocillopora and Stylophora (1.71 and 1.72, respectively) were from Marshall (2000), and were estimated for Galaxea based on a value of 1.63 for its relative Gardineroseris (Manzello, 2010) 
For chlorophyll and protein concentrations, as well as symbiont density, tissue of each nubbin was removed from the skeleton using an air pick, and collected in a beaker with $8 \mathrm{ml}$ of $0.45 \mu \mathrm{m}$ filtered seawater. The tissue slurry was homogenized using a Potter tissue grinder and a $1 \mathrm{ml}$ sub-sample was taken for symbiont counts, which were made using an inverted microscope (Leica, Wetzlar, Germany) and the Histolab 5.2.3 image analysis software (Microvision, Every, France). Five millilitres of the remaining tissue slurry was centrifuged at $8000 \mathrm{~g}$ for $10 \mathrm{~min}$. The supernatant was removed and the symbionts were re-suspended in $5 \mathrm{ml}$ of acetone for extraction of chlorophylls $a$ and $c_{2}$ during $24 \mathrm{~h}$ in darkness. Chlorophyll content was determined using a spectrophotometry method according to Jeffrey and Humphrey (1975). The remaining slurry was incubated in sodium hydroxide $(0.5 \mathrm{~N})$ maintained in a water bath for $30 \mathrm{~min}$ at $90^{\circ} \mathrm{C}$ for protein determination. Briefly, concentrations were estimated using a bicinchoninic acid protein assay (Uptima, Interchim) by reference to standards across a concentration range from 0 to $2000 \mu \mathrm{g} \mathrm{ml}^{-1}$ that were prepared using bovine serum albumin (Interchim). Absorbance was measured at $560 \mathrm{~nm}$, and sample protein content was determined using GENESIS (Kontron Instruments), and was normalized to the skeletal surface area.

Lipid content was quantified according to Hoogenboom et al. (2010) using a modification of the method developed by Bligh and Dyer (1959). Briefly, frozen nubbins were ground into a fine powder using a mortar and pestle and mixed with a solution of dichloromethane, methanol and distilled water. Samples were sonicated for $10 \mathrm{~min}$, incubated at $40^{\circ} \mathrm{C}$ for $1 \mathrm{~h}$ and filtered through Whatman $\mathrm{GF} / \mathrm{C}$ filters to remove skeleton fragments from solution. Subsequently, $1.5 \mathrm{ml}$ of both dichloromethane and methanol were added to the filtrate and the solution was centrifuged at $3000 \mathrm{~g}$ for $10 \mathrm{~min}$ to separate the phases. The lower lipid-containing layer was transferred into cleaned, pre-combusted and pre-weighed glass vials $(4 \mathrm{ml})$. The solution was evaporated under nitrogen, and the amount of lipid was determined by weight.

\section{Carbon and nitrogen isotopic determination}

Carbon and nitrogen isotopic determination was performed in each component of the symbiotic association (symbionts and host) to trace how nutrients are shared within the symbiosis. We expected that heterotrophic feeding would change the isotopic composition of the host tissue more than the symbionts because particulate nutrients are first ingested and digested by the coral host. Nubbins were individually placed in $100 \mathrm{ml}$ beakers, containing $20 \mathrm{ml}$ of filtered seawater, which had been pre-combusted at $480^{\circ} \mathrm{C}$ for at least $4 \mathrm{~h}$ in a ThermolyneH 62700 oven. Tissue was completely removed from the skeleton with an air pick and homogenized with a Potter tissue grinder. The homogenate was separated into host and symbiont fractions by centrifugation at $3000 \mathrm{~g}$ for $10 \mathrm{~min}$ to pellet the symbionts (at $4^{\circ} \mathrm{C}$ ). Centrifugation of the supernatant was repeated twice to entirely remove any remaining symbionts, and the supernatant was subsequently flash frozen in liquid nitrogen, and freeze-dried using a Heto (model CT 60) drier. For the symbiont fraction, the pellet was washed several times with filtered seawater (to remove any residual host tissue) before being flash frozen and freeze-dried as above. Samples were analyzed for $\delta^{15} \mathrm{~N}$ and $\delta^{13} \mathrm{C}$ using a Geo-20:20 isotope ratio mass spectrometer (SerConH). Scale calibration of results was performed using international reference materials (IAEA-600 and IAEA-CH6, International Atomic Energy Agency) and two control samples were analyzed with each batch for quality control purposes. Precision, as determined by repeat analysis of controls and reference materials, was better than $\pm 0.20 \%$ and $\pm 0.15 \%$ for measured $\delta^{15} \mathrm{~N}$ and $\delta^{13} \mathrm{C}$ values, respectively.

\section{Data analysis}

Values reported in the text are given as means \pm standard error. Two-way mixed-effects ANOVA was used to determine whether provision of food affected coral energy acquisition and allocation, with species and feeding regime treated as fixed factors, and tank was included as a random effect. Raw data were square root or log transformed so that the data were appropriate for ANOVA, as assessed by visual inspection of normal Q-Q plots and plots of residuals versus fitted values. Stable isotope data were analysed using general linear mixed-effects models to account for the repeated measure of different tissues (i.e. symbiont tissue and host tissue) sampled from the same coral fragment. In this analysis, coral fragment identity was treated as a random factor and the error term of the mixedeffects model specified that tissue type was nested within fragment. For all analyses, minimal models are presented with non-significant terms removed using a backwards deletion procedure. Analyses were implemented in $\mathrm{R}$ (version 2.14.1, R Core Development Team, 2011) using the function 'Ime' in the package 'nlme'.

The contribution of heterotrophic feeding to animal respiration (i.e. CHAR, after Grottoli et al., 2006) was calculated by multiplying feeding rate (measured as nauplii $\mathrm{cm}^{-2} \mathrm{~h}^{-1}$ ) by the carbon content of nauplii $\left(0.68 \mu \mathrm{g} \mathrm{C}\right.$ nauplii ${ }^{-1}$, Wijgerde et al., 2011) by the duration of the feeding period $(2 \mathrm{~h})$ and then dividing this rate by the measured respiration rate converted to carbon equivalents with values normalized to tissue surface area (as per Hoogenboom et al., 2010). Energy allocation to skeleton growth was calculated from the measured total calcification across the experiment (g) multiplied by the energy cost of calcification $\left(0.152 \mathrm{~J} \mathrm{mg}^{-1}\right.$, Anthony et al., 2002). Differences in energy allocation to tissue versus skeletal growth were determined by first converting the measured calcification per coral fragment (change in buoyant weight, g) into a change in colony volume $\left(\mathrm{cm}^{3}\right)$ given the density of the calcium carbonate skeleton (where increase in colony volume $\left[\mathrm{cm}^{3}\right]=$ production of new skeleton $[\mathrm{g}]$ divided by skeletal density $\left.\left[\mathrm{g} \mathrm{cm}^{-3}\right]\right)$. Subsequently, we calculated the increase in surface area that corresponded to the calculated increase in colony volume based on coral nubbin morphology. To do so, we represented fragments as cylinders with a 'branch' radius of $6 \mathrm{~mm}$ for Stylophora and Pocillopora and $4 \mathrm{~mm}$ for Acropora, or as plates with a height of $5 \mathrm{~mm}$ for Turbinaria and $10 \mathrm{~mm}$ for Galaxea. Geometric formulae for the surface area and volume of a cylinder were used to calculate the change in tissue surface area corresponding to the measured change in volume. Energy allocation to tissue was then estimated from the calculated change in tissue surface area multiplied by the measured lipid and protein content per unit surface area (converted to energy equivalents of $23.9 \mathrm{~J} \mathrm{mg}^{-1}$ for protein and $39.5 \mathrm{~J} \mathrm{mg}^{-1}$ for lipid, Gnaiger and Bitterlich, 1984). We did not account for carbohydrates because they typically contribute less than $10 \%$ of coral tissues (Leuzinger et al., 2003). Finally, given that these calculations depend on several parameters that are estimated with error, we conducted a sensitivity analysis to assess how variation in parameter values influenced proportional energy allocation to tissue (see Fig. S1).

\section{Carbon acquisition of simulated coral assemblages}

Total carbon uptake (from net photosynthesis and heterotrophic feeding) was simulated for different coral assemblages composed of different combinations of the study species. We used the measured data (photosynthesis, respiration, heterotrophic feeding, lipid content and protein content), and scaled up from measurements per unit tissue surface to values per square metre of reef taking into account the surface area to horizontal planar area ratios of the different genera. For the (flat) laminar/ encrusting morphologies (Galaxea and Turbinaria), colony tissue surface area is equivalent to horizontal planar area. For the branching morphologies, colony tissue surface area was calculated based on measured branch densities (branches $\mathrm{cm}^{-2}$ ) for Acropora valida (as a proxy for Acropora sp. used herein) and P. damicornis (as a proxy for Pocillopora and Stylophora used herein). These branch density estimates were determined from field photographs of $A$. valida and $P$. damicornis from Lizard Island (northern Great Barrier Reef) and Orpheus Island (central Great Barrier Reef). All photographs were taken from directly above coral colonies and included a ruler as a scale bar and were analysed using ImageJ. Branch surface area (based on branch diameter) was calculated for each genus, and then multiplied by branch density to obtain tissue surface area per unit reef occupied (i.e. horizontal planar area). To account for effects of morphological variation within species (e.g. Turbinaria colonies range from encrusting to cone-shaped with multiple tiers), we repeated the calculations for different colony shapes. Moreover, previous studies indicate that different proportions of the coral tissue surface actively capture particles from the water column, ranging from branch tips (Palardy et al., 2005) to branch bases at the centre of colonies where plankton can become trapped in interstitial spaces (Schiller and Herndl, 1989). To account for this, 
we repeated calculations for branching assemblages allowing active particle feeding for different proportions of the total colony surface area. For each simulated coral assemblage we calculated total carbon uptake ( $\mathrm{g} \mathrm{C} \mathrm{m}^{-2} \mathrm{day}^{-1}$, with daily respiration subtracted from daily photosynthesis and converted to carbon equivalents as above), particulate carbon uptake ( $\mathrm{g} \mathrm{C} \mathrm{m}^{-2} \mathrm{day}^{-1}$, calculated based on feeding rates and an estimated carbon content of plankton of $0.68 \mu \mathrm{g} \mathrm{C}$ plankton ${ }^{-1}$; see above) and total coral tissue biomass $\left(\mathrm{g} \mathrm{m}^{-2}\right.$, calculated as the sum of protein and lipid content per unit surface area multiplied by colony tissue surface area). We note that these calculations assume that area-specific rates are independent of colony diameter and are intended to identify relative variation among the assemblages rather than to predict absolute rates of carbon uptake under field conditions.

\section{RESULTS}

Among-species variation in symbiont properties and carbon acquisition

The effect of feeding on the density of symbionts within coral tissue varied among the study species (Table 1). Provision of food enhanced symbiont density for Acropora, Pocillopora and Stylophora but not for Galaxea or Turbinaria (Fig. 1A). Among the five species, Stylophora had the highest average symbiont density, but values for this species were similar to those of Turbinaria and Galaxea (Tukey's HSD, $P>0.75$ for both comparisons), while densities for Acropora and P. damicornis were 2-3-fold lower (Fig. 1A). Variation in total chlorophyll concentration (chl $a+c_{2}$ ) in response to feeding was generally consistent with observed variation in symbiont densities for Acropora, Pocillipora and Turbinaria (Fig. 1B), although this difference was not significant for Pocillopora (post hoc test, $P=0.07)$. However, fed nubbins of Stylophora did not have higher chlorophyll content than unfed nubbins, despite the increase in symbiont population density with feeding, reflecting a decrease in chlorophyll per symbiont cell for fed nubbins (data not plotted). Conversely, chlorophyll content was significantly higher in fed nubbins of Turbinaria, although feeding did not significantly enhance symbiont numbers for this species.

Neither rates of photosynthesis nor dark respiration varied significantly with food availability for any of the study species (Table 1), despite a general trend toward increased photosynthesis rates in fed nubbins of all species except for Turbinaria (Fig. 1C). Measured rates of dark respiration (Fig. 1D) were approximately equivalent for all species except for Acropora, for which rates were $\sim 3$-fold lower, and were not influenced by food availability (Table 1, Fig. 1D). Grazing rates of coral nubbins on Artemia salina nauplii ranged between $9.6 \pm 3.6$ to $188 \pm 15.9$ nauplii $\mathrm{cm}^{-2} \mathrm{~h}^{-1}$ for Acropora and Pocillopora, respectively, with the other species intermediate in this range (Table 2). The ratio of photosynthesis to respiration, converted to units of $\mu \mathrm{g} \mathrm{Cm}^{-2}$ day $^{-1}$, ranged from $1.06 \pm 0.14$ for Pocillopora to $1.41 \pm 0.08$ for Galaxea with the other species intermediate within this range (Table 2). The contribution of total acquired carbon to animal respiration (CTAR, calculated as the sum of daily photosynthetic plus heterotrophic carbon acquisition relative to daily respiration) was $>100 \%$ for all species (Table 2), with Pocillopora $>$ Stylophora $>$ Acropora $>$ Galaxea $>$ Turbinaria .

\section{Among-species variation in calcification and tissue composition}

Skeleton growth over the total duration of the experimental period ranged from 0.14 to $3.8 \mathrm{~g}$ and was highest for Turbinaria and Stylophora, which showed approximately equivalent growth of $2.3 \pm 0.27$ and $1.7 \pm 0.16 \mathrm{~g}$, respectively, compared with $\sim 0.50$ to $0.75 \mathrm{~g}$ for the other species. Skeleton growth was generally higher
Table 1. Mixed-effects ANOVA of the effect of feeding on bioenergetics of five coral species (Stylophora pistillata, Turbinaria reniformis, Acropora sp., Pocillopora damicornis and Galaxea fascicularis), where tank was included as a random effect

\begin{tabular}{|c|c|c|c|}
\hline Factor & d.f. & $F$ & $P$ \\
\hline \multicolumn{4}{|l|}{ Symbiont density } \\
\hline Species & 4,46 & 72 & $<0.001$ \\
\hline Feeding & 1,4 & 47 & $<0.01$ \\
\hline Species: & 4,46 & 3.9 & $<0.01$ \\
\hline \multicolumn{4}{|l|}{ Feeding } \\
\hline \multicolumn{4}{|l|}{ Chlorophyll content } \\
\hline Species & 4,46 & 91 & $<0.001$ \\
\hline Feeding & 1,4 & 38 & $<0.01$ \\
\hline Species: & 4,46 & 3.7 & $<0.05$ \\
\hline \multicolumn{4}{|l|}{ Feeding } \\
\hline \multicolumn{4}{|l|}{ Photosynthesis rate } \\
\hline Species & 4,46 & 10.8 & $<0.001$ \\
\hline Feeding & 1,4 & 1.8 & 0.26 \\
\hline Species: & 4,46 & 3.1 & $<0.05$ \\
\hline \multicolumn{4}{|l|}{ Feeding } \\
\hline \multicolumn{4}{|l|}{ Respiration rate } \\
\hline Species & 4,50 & 8.0 & $<0.001$ \\
\hline Feeding & 1,4 & 0.7 & 0.45 \\
\hline \multicolumn{4}{|l|}{ Protein content } \\
\hline Species & 4,50 & 58 & $<0.001$ \\
\hline Feeding & 1,4 & 21 & $<0.05$ \\
\hline \multicolumn{4}{|l|}{ Lipid concentration } \\
\hline Species & 4,46 & 35 & $<0.001$ \\
\hline Feeding & 1,4 & 23 & $<0.01$ \\
\hline Species: & 4,46 & 4.0 & $<0.01$ \\
\hline \multicolumn{4}{|l|}{ Feeding } \\
\hline \multicolumn{4}{|l|}{ Calcification rate } \\
\hline Species & 4,50 & 29 & $<0.001$ \\
\hline Feeding & 1,4 & 4.4 & 0.11 \\
\hline \multicolumn{4}{|l|}{ Skeletal density } \\
\hline Species & 4,50 & 9.8 & $<0.001$ \\
\hline Feeding & 1,4 & 0.01 & 0.93 \\
\hline \multicolumn{4}{|l|}{$13 \mathrm{C}$} \\
\hline Species & 4,20 & 8.5 & $<0.001$ \\
\hline Feeding & 1,20 & 16 & $<0.001$ \\
\hline Tissue & 1,25 & 93 & $<0.001$ \\
\hline Species: & 4,20 & 6.1 & $<0.01$ \\
\hline \multicolumn{4}{|l|}{ Feeding } \\
\hline Species:Tissue & 4,25 & 9.2 & $<0.001$ \\
\hline \multicolumn{4}{|l|}{$15 \mathrm{~N}$} \\
\hline Species & 2,11 & 55 & $<0.001$ \\
\hline Feeding & 1,11 & 52 & $<0.001$ \\
\hline Tissue & 1,12 & 0.17 & 0.69 \\
\hline Species:Tissue & 2,12 & 4.7 & $<0.05$ \\
\hline
\end{tabular}

Non-significant interaction terms were removed from the analyses, and data were square root or log transformed where required to enable the use of parametric ANOVA.

for fed compared with unfed nubbins overall, but this effect was not statistically significant (Table 1, Fig. 2A), nor did it depend on species identity (ANOVA, species by feeding interaction term, $\left.F_{4,50}=1.5, P=0.21\right)$. Skeletal micro-density was not influenced by food availability (Table 1, Fig. 2D), but Galaxea had higher skeletal density than all other species (post hoc test, pairwise comparisons between Galaxea and other species, $P<0.03$ in all cases). Pocillopora and Turbinaria had the lowest skeletal density, although density of Turbinaria was not significantly different than that of Stylophora and Acropora, which had intermediate density (Fig. 2D).

Tissue composition varied among species and in response to feeding. Protein content was highest, on average, for nubbins of Turbinaria $\left(1.9 \pm 0.12 \mathrm{mg} \mathrm{cm}^{-2}\right)$ followed by Galaxea (1.2 \pm $0.07 \mathrm{mg} \mathrm{cm}^{-2}$ ), and levels for these species were significantly 


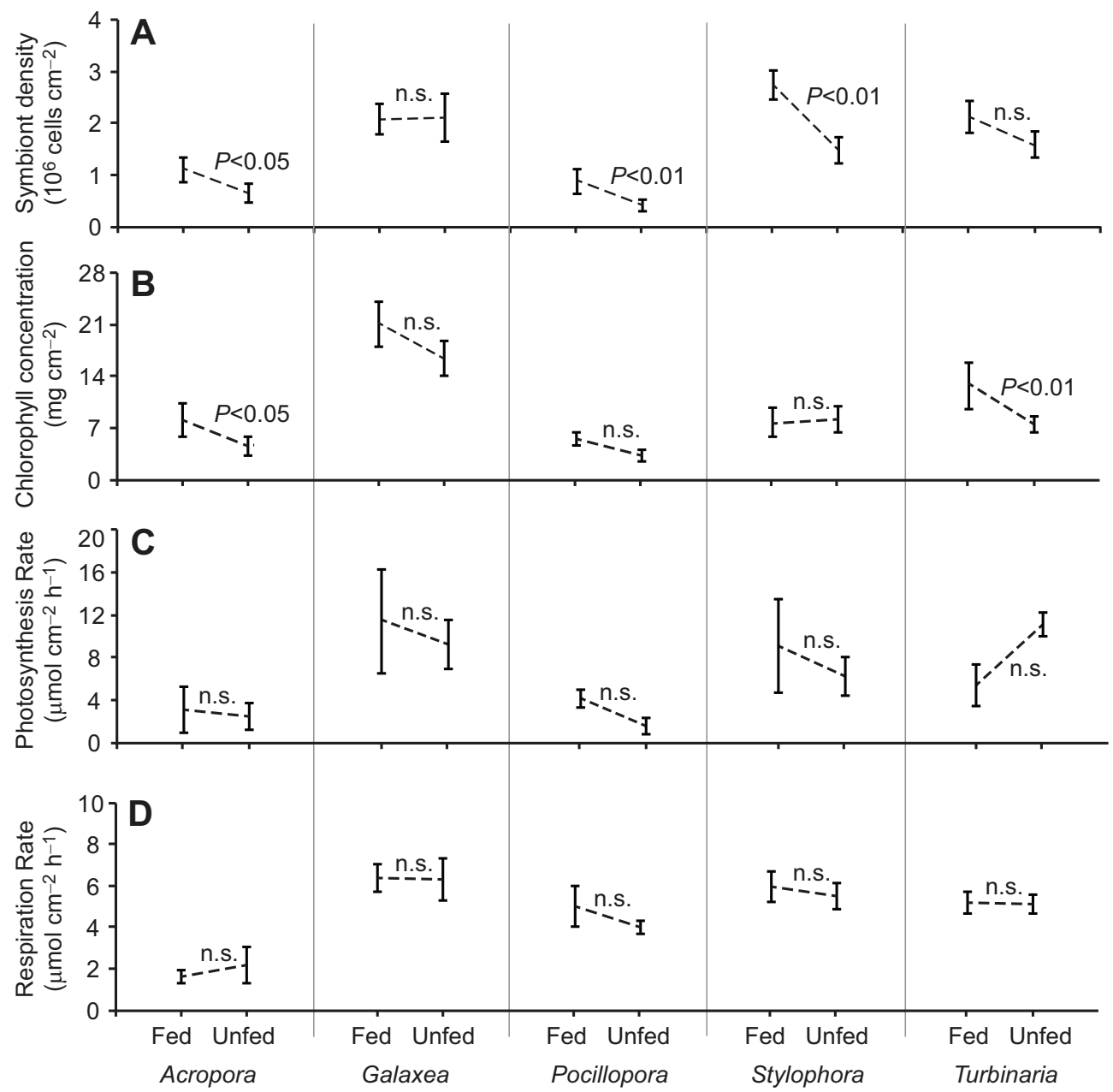

Fig. 1. Effect of feeding on photosynthetic energy acquisition for five species of reef-building corals (Stylophora pistillata, Turbinaria reniformis, Acropora sp., Pocillopora damicornis and Galaxea fascicularis). Error bars show standard deviation around mean values observed for each parameter and each species ( $n=5$ or 6$)$, and points joined by dashed lines depict the magnitude of the feeding effect on (A) symbiont density, (B) chlorophyll concentration, $(C)$ photosynthesis rate and (D) respiration rate. ns denotes a nonsignificant within-species feeding effect. different from each other and from those of the three branching species (Tukey's HSD, $P<0.01$ for all comparisons). As observed for skeletal growth rates, protein levels were higher in fed compared with unfed nubbins overall (Tables 1 and 3), independent of species identity (ANOVA, species by feeding interaction term, $F_{4,50}=1.3, P=0.30$, Fig. 2B). In contrast to the consistent effect of feeding on tissue protein, lipid concentrations were only significantly higher in fed compared with unfed nubbins of Pocillopora and Turbinaria (Fig. 2C). On average, Stylophora had the highest lipid content $\left(1.3 \pm 0.09 \mathrm{mg} \mathrm{cm}^{-2}\right)$, Pocillopora had the lowest lipid content $\left(0.56 \pm 0.09 \mathrm{mg} \mathrm{cm}^{-2}\right)$ and the other three species were intermediate between these levels.

\section{Symbiont and host tissue isotopic ratios}

$\delta^{15} \mathrm{~N}$ isotopic values ranged from $\sim 3.3$ to $8.3 \%$ overall, but comparison of the effects of tissue type (host versus symbont) and food availability (fed versus unfed) could only be conducted for three species because of missing data for symbionts within unfed nubbins of Acropora and Pocillopora. This analysis revealed that fed corals (overall, pooled across species and tissue type), tended to have higher $\delta^{15} \mathrm{~N}$ (feeding main effect, Table 1) than unfed corals. However, host and symbiont tissues only differed in $\delta^{15} \mathrm{~N}$ for Stylophora (post hoc test, host versus symbiont comparison, $P=0.17$ and 0.35 for Galaxea and Turbinaria, respectively, Fig. 3A). When only the fed nubbins of all species were compared in a separate analysis, symbiont $\delta^{15} \mathrm{~N}$ values were higher than those of host tissue for Stylophora (post hoc test, host versus symbiont comparison, $P<0.02$ ), lower than those of host tissue for Pocillopora (post hoc test, host versus symbiont comparison, $P<0.001$ ) but equivalent for the remaining three species ( post hoc test, host versus symbiont comparison, $P>0.27$ in all cases, Fig. 3A). The $\delta^{13} \mathrm{C}$ isotopic ratio ranged from $\sim-29$ to

Table 2. Summary of the energy budget for fed corals of each of five species showing carbon intake from different sources

\begin{tabular}{lllll}
\hline & \multicolumn{3}{l}{ Carbon budget } \\
\cline { 2 - 5 } Species & $\begin{array}{l}\text { Feeding rate } \\
\text { (nauplii } \mathrm{cm}^{-2} \mathrm{~h}^{-1} \text { ) }\end{array}$ & $\begin{array}{l}\text { Heterotrophic carbon intake } \\
\text { relative to respiration (\%) }\end{array}$ & $\begin{array}{l}\text { Photosynthetic carbon intake } \\
\text { relative to respiration (\%) }\end{array}$ & $\begin{array}{l}\text { Total carbon intake relative } \\
\text { to respiration (\%) }\end{array}$ \\
\hline Acropora sp. & $9.6 \pm 3.6$ & $19 \pm 6.8$ & $140 \pm 17.7$ & $160 \pm 14$ \\
Galaxea fascicularis & $14.5 \pm 2.1$ & $14 \pm 1.1$ & $141 \pm 7.7$ & $156 \pm 7.8$ \\
Pocillopora damicornis & $188 \pm 15.9$ & $159 \pm 39$ & $106 \pm 13.4$ & $265 \pm 48$ \\
Stylophora pistillata & $103.8 \pm 11.9$ & $75 \pm 8.8$ & $128 \pm 8.6$ & $203 \pm 16$ \\
Turbinaria reniformis & $50.3 \pm 6.7$ & $36 \pm 3.8$ & $109 \pm 9.8$ & $145 \pm 13$ \\
\hline
\end{tabular}

Data are means \pm SEM. 


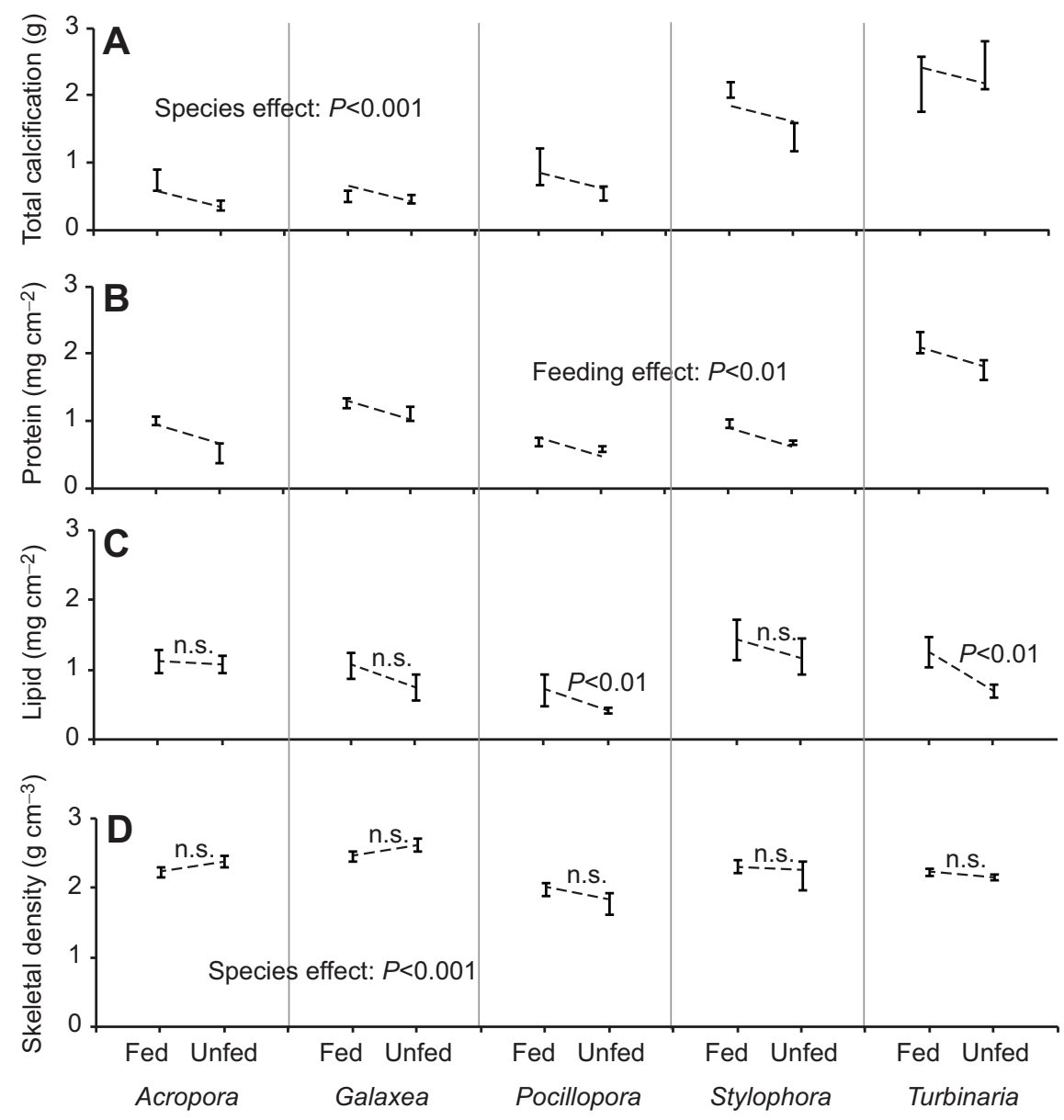

Fig. 2. Effect of feeding on energy allocation to skeleton and tissue for five species of reef-building corals. Error bars show standard deviation around mean values observed for each parameter and each species ( $n=5$ or 6 ), and points joined by dashed lines depict the magnitude of the feeding effect on (A) total calcification measured using wet buoyant weight, $(B, C)$ protein and lipid content, and (D) skeletal density. ns denotes a non-significant within-species feeding effect and $P$-values reported for protein relate to the main effect of feeding.

$\sim-11 \%$ and was more positive in symbiont compared with host tissue for Acropora, Galaxea and Pocillopora (Table 1, Fig. 3B). In addition, the $\delta^{13} \mathrm{C}$ isotopic ratio was higher in unfed compared with fed nubbins for Acropora (but not for the other four species; Table 3, Fig. 3B).

\section{Relationships between physiological traits and relative heterotrophic feeding rates}

The high variation in feeding rates corresponded to CHAR values between $14 \pm 1 \%$ and $159 \pm 39 \%$ for Galaxea and Pocillopora, respectively, with the other three species intermediate within this range (Fig. 4). Feeding rates were more variable between species than photosynthesis rates, and this meant that the rank order of species based on CTAR was generally similar to the rank order of species based on CHAR, with Pocillopora and Stylophora having considerably higher values than the other three species. Based on simple geometric relationships between surface area and volume of coral branches (Acropora, Pocillopora, Stylophora) and plates (Turbinaria, Galaxea), the proportion of energy allocated to tissue biomass (relative to skeletal growth) ranged from 31\% to $74 \%$ overall (absolute range across all nubbins). There was no evidence that allocation to tissue was higher in fed compared with unfed nubbins (data not plotted, two-way ANOVA, feeding effect on energy allocation, $\left.F_{1,50}=2.3, P=0.14\right)$. However, allocation did vary among

Table 3. Summary of the overall effects of heterotrophic feeding on physiological energetics for five coral species

\begin{tabular}{|c|c|c|c|c|c|}
\hline Physiological trait & Acropora sp. & Galaxea fascicularis & Pocillopora damicornis & Stylophora pistillata & Turbinaria reniformis \\
\hline Symbiont density & + & 0 & + & + & 0 \\
\hline Chlorophyll content & + & 0 & 0 & 0 & + \\
\hline Respiration rate & 0 & 0 & 0 & 0 & 0 \\
\hline Photosynthesis rate & 0 & 0 & 0 & 0 & 0 \\
\hline Calcification & 0 & 0 & 0 & 0 & 0 \\
\hline Lipid content & 0 & 0 & + & 0 & + \\
\hline Skeletal density & 0 & 0 & 0 & 0 & 0 \\
\hline $\begin{array}{l}\text { Protein content } \\
\text { Isotopic ratio }\end{array}$ & + & + & + & + & + \\
\hline$\delta^{15} \mathrm{~N}$ & n.d. & + & Fed only, Host<Sym & + , Host $>$ Sym. & + \\
\hline$\delta^{13} \mathrm{C}$ & + , Host $>$ Sym. & 0 , Host $>$ Sym. & 0, Host>Sym. & 0 & 0 \\
\hline
\end{tabular}

'+' denotes a positive effect of feeding and '0' denotes no effect. n.d. refers to 'no data' and 'Host>Sym' denotes a difference between coral host and Symbiodinium regardless of feeding treatment. The 'feeding' main effect in Table 1 for $\delta^{15} \mathrm{~N}$ only applies to Galaxea, Stylophora and Turbinaria because of missing data for the tissue fraction of unfed colonies of Acropora and Pocillopora. 


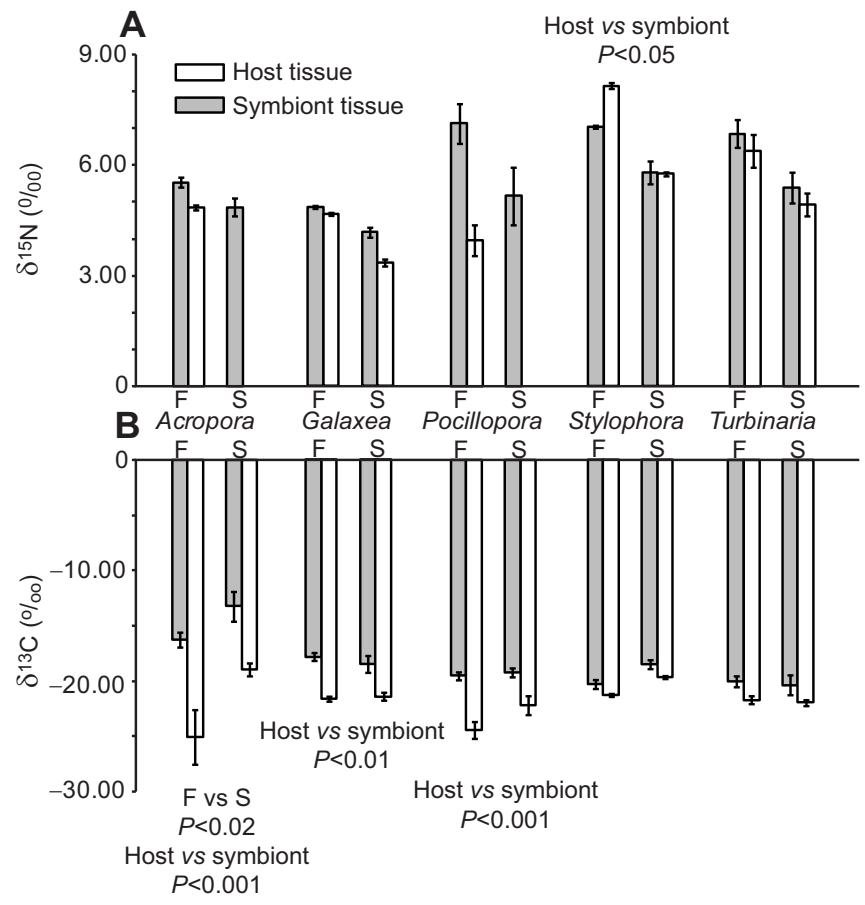

Fig. 3. Effect of feeding on the nitrogen and carbon isotopic composition of coral tissues. Bars show mean values for (A) nitrogen and (B) carbon for symbiont versus host tissue from five species of reef-building corals, differentiated by feeding regime ( $F$, fed; $S$, unfed). Values are measured relative to the isotopic composition of Vienna Pee Dee Belemnite (V-PDB) for carbon and relative to air for nitrogen, and the zero point is a relative rather than absolute measure.

species (two-way ANOVA, species effect on energy allocation, $F_{4,50}=11.3, P<0.001$, Fig. 4A). Energy allocation was similar for Stylophora, Pocillopora and Turbinaria (Tukey's post hoc test, $P>0.58$ for all relevant pairwise comparisons), and values for these three species were lower than values for Galaxea and Acropora (Tukey's post hoc test, $P<0.02$ for all relevant pairwise comparisons).

Energy allocated to tissue versus skeleton was higher in species that had a lower reliance on heterotrophic feeding (Pearson's correlation between CHAR and energy allocation to tissue, arcsintransformed proportion data, $r=-0.49, t_{28}=-3.04, P<0.01$, Fig. 4 A). Note that only data for fed nubbins were analysed because $\mathrm{CHAR}=0$ for the unfed nubbins in our experiment. In contrast, there was not an obvious trend in the relationships between CHAR and the differences in $\delta^{13} \mathrm{C}$ and $\delta^{15} \mathrm{~N}$ between host and symbiont tissue from the same fragments (denoted by $\Delta \delta^{13} \mathrm{C}$ and $\Delta \delta^{15} \mathrm{~N}$, respectively, hereafter) because the values for Pocillopora were not consistent with the trend observed for the other four species. For the carbon isotopic ratio, the largest differences in host and symbiont values occurred when CHAR was very low $(<30 \%)$ or very high $(>150 \%)$. For nitrogen, differences between host and symbiont values occurred when CHAR was $>70 \%$, but this difference was positive for Stylophora and negative for Pocillopora.

Differences in $\Delta \delta^{13} \mathrm{C}$ between host and symbiont tissues were generally consistent with differences in $\Delta \delta^{15} \mathrm{~N}$ between host and symbiont, except for Pocillopora (Fig. 4B,C). When data from both fed and unfed colonies were included there was a general trend toward a larger $\Delta \delta^{13} \mathrm{C}$ associated with increased $\Delta \delta^{15} \mathrm{~N}$ (Fig. 5). However, this relationship was not statistically significant (Pearson's correlation, $R=-0.38, t_{19}=-1.8, P=0.09$ ) as there was high variation in $\Delta \delta^{15} \mathrm{~N}$ for colonies for which $\Delta \delta^{13} \mathrm{C}$ values were
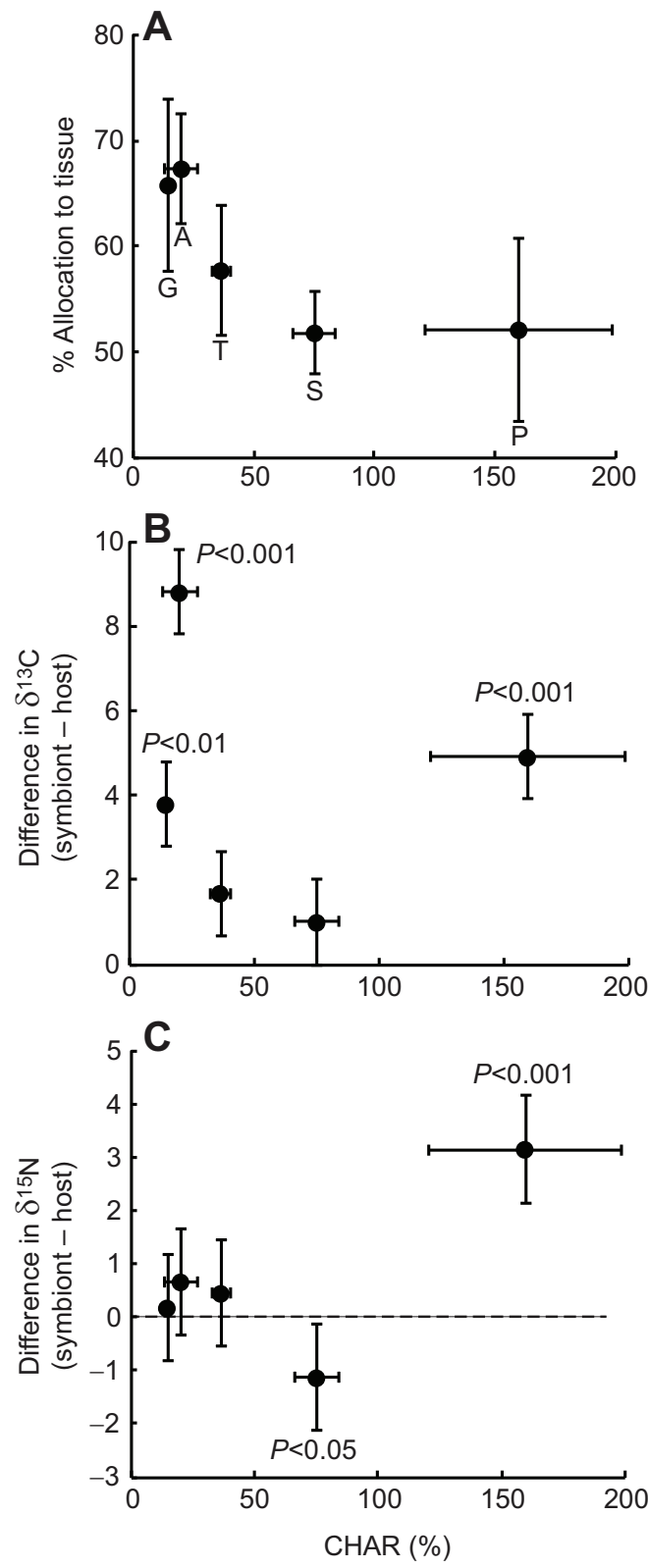

Fig. 4. Relationships between relative heterotrophic feeding capacity (CHAR) and coral energy allocation and tissue isotopic composition. Points show (A) energy allocation to tissue versus skeleton (\%) for coral colonies; (B) difference (\%) between host and symbiont ${ }^{13} \mathrm{C}$ isotopic ratio, and (C) difference (\%o) between host and symbiont ${ }^{15} \mathrm{~N}$ isotopic ratio. Only data for the fed colonies were included in the analyses (and plots), and error bars show standard error. $P$-values in $B$ and $C$ indicate whether host and symbiont values different significantly within species, and $S, T, A, P$ and $G$ denote values for Stylophora, Turbinaria, Acropora, Pocillopora and Galaxea, respectively. Values in $\mathrm{B}$ and $\mathrm{C}$ are measured relative to the isotopic composition of $\mathrm{V}$-PDB for carbon and relative to air for nitrogen, and the zero point is a relative rather than absolute measure.

small. In addition, there were two colonies that showed values inconsistent with the general trend (two Acropora with $\Delta \delta^{13} \mathrm{C}>8$ but $\Delta \delta^{15} \mathrm{~N} \sim 1$ ). In contrast, the magnitude of the difference between host and symbiont values was correlated with symbiont density within coral tissue for $\delta^{15} \mathrm{~N}$ (Pearson's correlation, $R=-0.77$, $t_{6}=-2.9, P<0.03$, Fig. 6B) with a similar, but not statistically significant, association observed for $\delta^{13} \mathrm{C}$ (Pearson's correlation, $R=-0.53, t_{8}=-1.8, P=0.12$, Fig. $\left.6 \mathrm{~A}\right)$. 


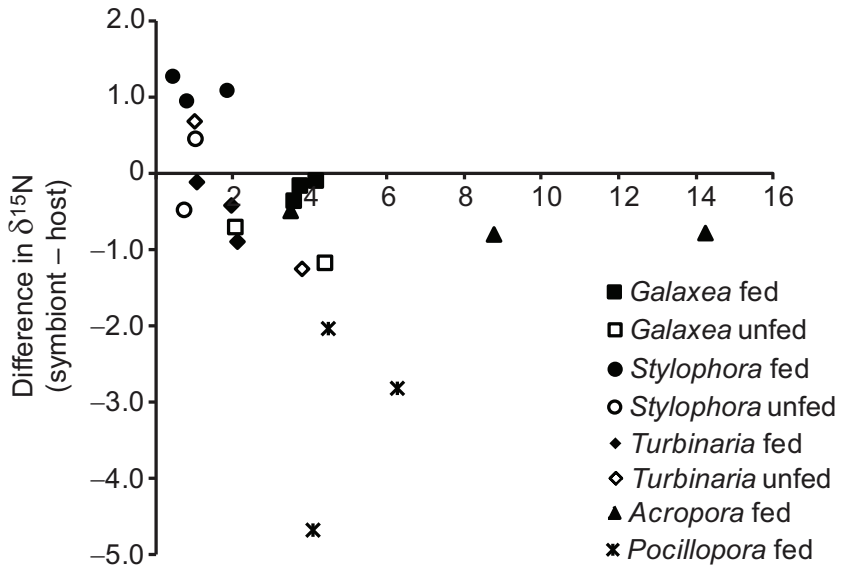

Difference in $\delta^{13} \mathrm{C}$

(symbiont - host)

Fig. 5. Relationship between the difference between coral host and symbiont isotopic composition for carbon and nitrogen isotopes. Data points represent values for individual colonies for which both $\delta^{15} \mathrm{~N}$ and $\delta^{13} \mathrm{C}$ data for both host and symbiont were obtained $(N=20)$. Both fed and unfed colonies of all five study species were included in this analysis.

\section{Carbon acquisition of simulated coral assemblages}

Net carbon uptake of simulated coral assemblages varied $>20$-fold depending on species composition (Table 4). The assemblage composed of only encrusting/laminar colony morphologies (i.e. Galaxea and Turbinaria) had the lowest total carbon uptake $\left(\sim 0.76 \mathrm{~g} \mathrm{C} \mathrm{m}^{-2}\right.$ day $\left.^{-1}\right)$ despite the relatively high gross photosynthesis rates of these genera (Fig. 1). In contrast, the assemblage composed of the three branching genera (i.e. Acropora, Stylophora and Pocillopora) had substantially higher total carbon uptake $\left(\sim 12.1 \mathrm{~g} \mathrm{C} \mathrm{m}^{-2} \mathrm{day}^{-1}\right)$ and higher particulate carbon uptake $\left(\sim 9.6 \mathrm{~g} \mathrm{C} \mathrm{m}^{-2}\right.$ day $\left.^{-1}\right)$. These differences were primarily driven by the much higher surface area to horizontal planar area ratio of branching compared with other morphologies (as indicated by the higher total tissue biomass of these assemblages, Table 4). Morphological plasticity, such as changes in colony shape observed for Turbinaria along a light intensity gradient, had a relatively small influence on particulate and total carbon uptake by coral assemblages (Table 4). In contrast, for branching species, decreasing the proportion of the tissue surface actively involved in particle capture substantially decreased whole-assemblage uptake of particulate carbon (Table 4). However, uptake by the assemblage of branching species remained higher than that of the non-branching species as long as the area of the effective feeding surface was $>6 \%$ of the total tissue surface area.

\section{DISCUSSION}

Of the 9 physiological traits measured in this study, tissue protein content was the most sensitive to the availability of particulate food, increasing in fed colonies of all five study species (as summarised in Table 3). Symbiont density and chlorophyll content were influenced by food availability only for certain species, whereas whole-colony photosynthesis and respiration rates were independent of feeding for all species. Despite among-species variation in physiology, and consistent effects of feeding on some traits, overall energy allocation to tissue compared with skeleton growth did not depend on feeding status, primarily because both calcification and tissue quality (protein content) were enhanced by feeding (although the effect of feeding on calcification was not statistically significant). $\delta^{15} \mathrm{~N}$ was a
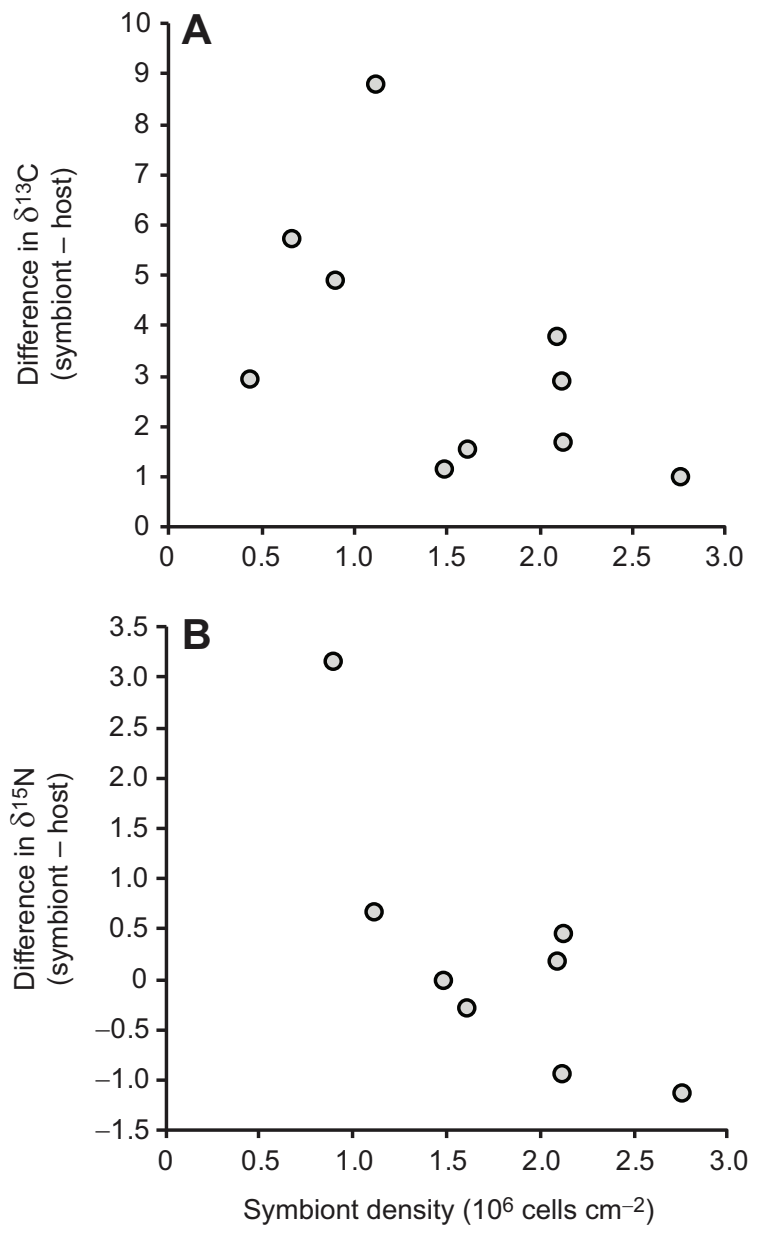

Fig. 6. Relationships between symbiont density and the difference between coral host and symbiont isotopic composition. Points show values for carbon $(A)$ and nitrogen $(B)$ isotopes. Data points represent values for individual colonies for which both $\delta^{15} \mathrm{~N}$ and $\delta^{13} \mathrm{C}$ data for both host and symbiont were obtained. Both fed and unfed colonies of all five study species were included in this analysis. There are fewer data points in $\mathrm{B}$ due to missing data for $\delta^{15} \mathrm{~N}$ for unfed colonies of Acropora and Pocillopora.

reliable indicator of heterotrophic feeding because it was higher in tissues of fed Galaxea and Turbinaria, significantly different between symbiont and host for Stylophora and Pocillopora (data available for fed corals only) and the difference in $\delta^{15} \mathrm{~N}$ between host and symbiont decreased with increasing symbiont density. Finally, estimated whole-community carbon uptake varied $>20$-fold across different simulated coral assemblages. However, this variation was driven by differences in the tissue surface area to horizontal planar area ratio for different colony morphologies, and by differences in the effective feeding surface area of branching morphologies. Clearly, accurately quantifying the size of the effective feeding surface area is important for accurate prediction of particulate matter uptake by coral assemblages.

\section{Nutrient sharing between coral host and symbionts}

Stable isotopes are increasingly used in dietary and food web studies (Peterson and Fry, 1987) and are a valuable technique for tracking the exchange of nutrients within symbiotic associations (e.g. Hughes et al., 2010; Tremblay et al., 2014). To date, several studies of coral feeding ecology have quantified the difference between symbiont and coral host isotopic ratios, with larger differences implying a greater reliance on heterotrophy. Such inferences are supported by the general 
Table 4. Whole-community biomass and carbon uptake for simulated coral assemblages with a fixed horizontal planar area of $1.5 \mathrm{~m}^{2}$

\begin{tabular}{|c|c|c|c|}
\hline Coral assemblage & $\begin{array}{l}\text { Net carbon uptake }(\mathrm{g} \mathrm{C} \\
\left.\mathrm{m}^{-2} \text { day }^{-1}\right)\end{array}$ & $\begin{array}{l}\text { Particulate carbon uptake (g C } \\
\mathrm{m}^{-2} \text { day }^{-1} \text { ) }\end{array}$ & Tissue biomass $\left(\mathrm{g} \mathrm{m}^{-2}\right)$ \\
\hline (A) Galaxea, Turbinaria (0.75 $\mathrm{m}^{2}$ per genus) & $0.66-0.87$ & $0.25-0.63$ & $24-33$ \\
\hline with conical Turbinaria & $0.66-0.87$ & $0.25-0.63$ & 24-33 \\
\hline with conical multi-tier Turbinaria & $0.86-1.1$ & $0.36-0.89$ & $32-45$ \\
\hline (B) Acropora, Stylophora, Pocillopora (0.5 m² per genus) & $9.9-12.9$ & $7.2-10.5$ & 139-206 \\
\hline Particle capture by $75 \%$ of polyps & & $5.4-7.9$ & \\
\hline Particle capture by $50 \%$ of polyps & & $3.6-5.3$ & \\
\hline Particle capture by $25 \%$ of polyps & & $1.8-2.6$ & \\
\hline $\begin{array}{l}\text { (C) Acropora, Stylophora, Pocillopora, Galaxea, } \\
\text { Turbinaria ( } 0.3 \mathrm{~m}^{2} \text { per genus) }\end{array}$ & $6.2-8.1$ & $4.5-6.6$ & $93-137$ \\
\hline
\end{tabular}

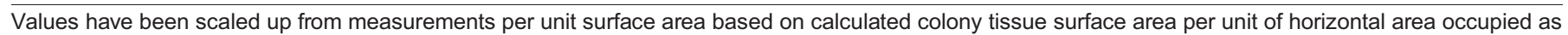

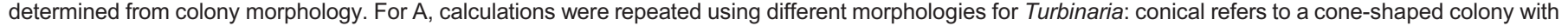

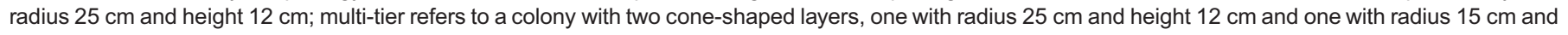
height $20 \mathrm{~cm}$. For B, calculations were repeated assuming different proportions of the coral tissue area actively captured particles.

trend of increased differentiation between host and symbiont isotope ratios as depth and heterotrophy increase to compensate for the decrease in light and photosynthetic productivity (Land et al., 1975; Muscatine and Kaplan, 1994; Lesser et al., 2010). In natural field settings, coral symbiont density, or the chlorophyll content of symbionts, tends to increase with depth to maximise light interception (Porter et al., 1984; Titlyanov et al., 2001; Frade et al., 2008). In this study we observed that host and symbiont isotopic composition were more similar in corals with high symbiont densities, suggesting that increased translocation of nutrients from coral host to symbiont (e.g. because of increased particulate feeding by the host) may drive an increase in symbiont density and a corresponding similarity in host and symbiont isotopic composition.

Our results suggest that nitrogen is exchanged and shared differently between coral host and symbionts compared with carbon: carbon isotopic composition was significantly different between coral and symbiont tissues for Acropora, Galaxea and Pocillopora, whereas nitrogen isotopic composition was significantly different between coral and symbiont tissues for Stylophora and Pocillopora. Although further studies on a greater number of species are required, our study suggests that differences between symbiont and host are associated with CHAR: variation in $\delta^{13} \mathrm{C}$ values occurred only when CHAR was very low or very high, and variation in $\delta^{15} \mathrm{~N}$ was only observed in species for which CHAR was above $70 \%$. Differentiation between host and symbiont when CHAR is high is consistent with what is reported in the broader literature. However, differentiation in host and symbiont $\delta^{13} \mathrm{C}$ for Acropora and Galaxea, species that had low CHAR values, indicates that $\delta^{15} \mathrm{~N}$ may be a more reliable indicator of coral heterotrophic feeding than $\delta^{13} \mathrm{C}$. Nevertheless, carbon translocation from symbiont to host can vary with particle feeding rates (Hughes et al., 2010; Tremblay et al., 2014) and a decrease in the amount of carbon translocated to the host when feeding rates are low and nutrient supply is limited could drive differentiation in host and symbiont $\delta^{13} \mathrm{C}$. Finally, we note that the $\delta^{13} \mathrm{C}$ values for symbiont and host observed here are more negative compared with other studies (e.g. -11 to $-14 \%$ in Nahon et al., 2013; or -13 and $-16 \%$ in Swart, 1983). Likely explanations for this observation include the relatively low light levels under which corals were grown in our study: several studies have found decreasing $\delta^{13} \mathrm{C}$ with depth (e.g. Grottoli and Wellington, 1999; Alamaru et al., 2009; Lesser et al., 2010). In addition, these values are likely to depend upon the nutritional value of the food source and the observed $\delta^{13} \mathrm{C}$ signal may reflect that of the Artemia used in our study (-29\%o, 1.24 $0.5 \mu \mathrm{g} \mathrm{C}$ nauplii ${ }^{-1}$ and $0.25 \pm 0.01 \mu \mathrm{g} \mathrm{N}$ nauplii ${ }^{-1}$ ).

\section{Energy allocation between tissue and skeleton}

Results of this study indicate that resource (i.e. energy and nutrients) allocation between tissue and skeleton growth is not sensitive to changes in plankton availability. Most energy budget models allow for variation in energy allocation between growth, reproduction and basic maintenance across an individual's lifespan, depending on body size and food availability (e.g. McCauley et al., 1990). Similarly, over evolutionary time scales, selection can drive variation in energy allocation; for instance, among-species variation in energy allocation to reproduction in fishes is related to population-specific adult mortality rates (Lester et al., 2004). Research on corals indicates that tissue growth precedes skeletal growth, with corals increasing their tissue before new skeleton is produced (e.g. Ferrier-Pagès et al., 2003; Houlbrèque et al., 2004), which could lead to a tight coupling between tissue and skeleton growth that would constrain variation in relative energy allocation. More broadly, a fixed energy allocation pattern indicates that changes in particulate food availability are likely to cause a general decline in coral growth rather than a change in energy allocation occurring that maintains skeleton growth and the expense of tissue growth (or vice versa).

\section{Scaling from coral polyps to communities}

Our results demonstrate that there is high among-species variation in carbon uptake, and indicate that the fluxes of carbon into and out of coral assemblages are likely to vary in response to changes in species composition. While we acknowledge the limitations of extrapolating results from laboratory experiments to natural field environments, this study indicates that coral communities dominated by branching morphologies (with a high coral tissue surface area to planar area ratio) potentially take up a much greater amount of particulate and photosynthetic carbon, although their uptake of particulate carbon depends on the proportion of the tissue surface that encounters and captures prey. Branching corals also excrete $40-60 \%$ of acquired carbon (Crossland et al., 1980; Davies, 1984) and, hence, carbon fluxes from reefs dominated by branching species are likely to exceed those of other coral assemblages. Although few studies have systematically compared the total productivity of different coral assemblages, evidence in the literature supports the interpretation of greater carbon flux from assemblages dominated by branching corals. For example, Acropora-dominated communities produce 15.3 to $16.6 \mathrm{~g} \mathrm{C} \mathrm{m}^{-2}$ day $^{-1}$ (Gattuso et al., 1996 and Smith, 1981, respectively) compared with 1.3 to $9.9 \mathrm{~g} \mathrm{C} \mathrm{cm}^{-2}$ day $^{-1}$ for mixed benthic assemblages of corals, macroalgae and crustose coralline algae (Atkinson and Grigg, 1984; Bates, 2002; Gattuso et al., 1996). 
Consistent with studies of coral heterotrophy conducted over the past decade (e.g. Houlbrèque et al., 2004; Grottoli et al., 2006, 2014), our results demonstrate that particle feeding contributes substantially to the energy budgets of certain coral species, with CHAR values ranging between 14\% (for Galaxea) and 150\% (for Pocillopora). Moreover, CHAR is typically calculated based on macroplankton and is likely to be higher if all possible heterotrophic feeding sources are considered (e.g. Tremblay et al., 2011). This is of concern because the species composition and body size distribution of plankton are regulated by physical and chemical conditions (Richardson, 2008) and are likely to change under climate change conditions. Presently, there is limited direct evidence of spatial variation in the extent to which different coral reefs, and/or different assemblages of coral species, consume plankton and other particulate matter. However, studies using stable isotope techniques have shown that corals in deeper waters consume more plankton than corals in shallow habitats (Muscatine et al., 1989; Alamaru et al., 2009). Similarly, there is evidence of among-reef variation in the carbon and nitrogen isotopic composition of coral tissues (Heikoop et al., 2000), and a recent study has demonstrated that spatial variation in coral tissue composition was associated with variation in turbidity (Nahon et al., 2013). Nevertheless, it remains unclear whether such variation in tissue composition is due to corals in different areas consuming different amounts or types of particulate food, or whether corals in different areas have differential reliance on photosynthesis versus particulate feeding. High variation in feeding rates among coral species, and in CHAR and the effects of feeding on coral physiology (present study; Sebens et al., 1996; Ferrier-Pagès et al., 2011; Palardy et al., 2005), indicates that predicted changes to plankton communities, and nutrient and sediment run-off, under climate change scenarios (e.g. McKinnon et al., 2007; Richardson, 2008) may affect the relative abundances of coral species on reefs.

Understanding the causes and consequences of among-species variation in physiological energetics provides insight into the mechanisms that underlie changes in the fluxes of organic matter within reefs, and between reefs and the open ocean. In this study we measured multiple physiological traits for the same coral fragments to facilitate direct comparisons within and among species. Results show that tissue protein content is consistently higher when particulate food is available for corals in general, whereas effects of feeding on symbiont density and chlorophyll content were species-specific. Our findings suggest that energy allocation between tissue and skeletal growth is not sensitive to variation in food availability. Finally, estimated whole-community carbon uptake varied $>20$-fold across different simulated coral assemblages and, therefore, our results caution against drawing conclusions about reef productivity based solely on physiological rates measured per unit tissue surface area without accounting for differences in total tissue surface area among different colony morphologies. Overall, these findings indicate that the fluxes of carbon into and out of coral assemblages are likely to vary in response to changes in species composition.

\section{Acknowledgements}

This research was funded by the Government of the Principality of Monaco through the Centre Scientifique de Monaco (C.R., S.S., C.F.-P.), and James Cook University (M.H.)

\section{Competing interests}

The authors declare no competing or financial interests.

\section{Author contributions}

C.F.-P. and M.H. designed the experiment and wrote the paper, M.H. analysed the data, and C.R. and S.S. collected the data and contributed to writing the paper.

\section{Funding}

This research received no specific grant from any funding agency in the public, commercial or not-for-profit sectors.

\section{Supplementary information}

Supplementary information available online at

http://jeb.biologists.org/lookup/suppl/doi:10.1242/jeb.124396/-/DC1

\section{References}

Alamaru, A., Loya, Y., Brokovich, E., Yam, R. and Shemesh, A. (2009). Carbon and nitrogen utilization in two species of Red Sea corals along a depth gradient: insights from stable isotope analysis of total organic material and lipids. Geochim. Cosmochim. Acta 73, 5333-5342.

Anthony, K. R. N. (1999). Coral suspension feeding on fine particulate matter. J. Exp. Mar. Biol. Ecol. 232, 85-106.

Anthony, K. R. N. and Fabricius, K. E. (2000). Shifting roles of heterotrophy and autotrophy in coral energetics under varying turbidity. J. Exp. Mar. Biol. Ecol. 252 221-253.

Anthony, K. R. N., Connolly, S. R. and Willis, B. L. (2002). Comparative analysis of energy allocation to tissue and skeletal growth in corals. Limnol. Oceanogr. 47, 1417-1429.

Atkinson, M. J. and Grigg, R. W. (1984). Model of a coral reef ecosystem II. Gross and net benthic primary production at French Frigate Shoals, Hawaii. Coral Reefs 3, 13-22.

Ayukai, T. (1995). Retention of phytoplankton and planktonic microbes on coral reefs within the Great Barrier Reef, Australia. Coral Reefs 14, 141-147.

Bak, R. P. M., Joenje, M., de Jong, I., Lambrechts, D. Y. M. and Nieuwland, G. (1998). Bacterial suspension feeding by coral reef benthic organisms. Mar. Ecol. Prog. Ser. 175, 285-288.

Bates, N. R. (2002). Seasonal variability of the effect of coral reefs on seawater $\mathrm{CO}_{2}$ and air-sea $\mathrm{CO}_{2}$ exchange. Limnol. Oceanogr. 47, 43-52.

Bligh, E. G. and Dyer, W. J. (1959). A rapid method of total lipid extraction and purification. Can. J. Biochem. Physiol. 37, 911-917.

Borell, E. M., Yuliantri, A. R., Bischof, K. and Richter, C. (2008). The effect of heterotrophy on photosynthesis and tissue composition of two scleractinian corals under elevated temperature. J. Exp. Mar. Biol. Ecol. 364, 116-123

Bucher, D. J., Harriott, V. J. and Roberts, L. G. (1998). Skeletal micro-density, porosity and bulk density of acroporid corals. J. Exp. Mar. Biol. Ecol. 228, 117-136.

Budd, A. F., Fukami, H., Smith, N. D. and Knowlton, N. (2012). Taxonomic classification of the reef coral family Mussidae (Cnidaria: Anthozoa: Scleractinia). Zool. J. Linn. Soc. 166, 465-529.

Caroselli, E., Prada, F., Pasquini, L., Marzano, F. N., Zaccanti, F., Falini, G. Levy, O., Dubsinsky, Z. and Goffredo, S. (2011). Environmental implications of skeletal micro-density and porosity variation in two scleractinian corals. Zoology $114,255-264$

Crossland, C. J., Barnes, D. J. and Borowitzka, M. A. (1980). Diurnal lipid and mucus production in the staghorn coral Acropora acuminata. Mar. Biol. 60 81-90

Davies, P. S. (1984). The role of zooxanthellae in the nutritional energy requirements of Pocillopora eydouxi. Coral Reefs 2, 181-186.

Davies, P. S. (1989). Short-term growth measurements of corals using an accurate buoyant weighing technique. Mar. Biol. 2, 181-186.

Devlin, M. J. and Brodie, J. (2005). Terrestrial discharge into the Great Barrier Reef Lagoon: nutrient behavior in coastal waters. Mar. Poll. Bull. 51, 9-22.

Fabricius, K. E. and Dommisse, M. (2000). Depletion of suspended particulate matter over coastal reef communities dominated by zooxanthellate soft corals. Mar. Ecol. Prog. Ser. 196, 157-167.

Ferrier, M. D. (1991). Net uptake of dissolved free amino acids by four scleractinian corals. Coral Reefs 10, 183-187.

Ferrier-Pagès, C., Witting, J., Tambutté, E. and Sebens, K. P. (2003). Effect of natural zooplankton feeding on the tissue and skeletal growth of the scleractinian coral Stylophora pistillata. Coral Reefs 22, 229-240.

Ferrier-Pagès, C., Hoogenboom, M. and Houlbreque, F. (2011). The role of plankton in coral trophodynamics. In Coral Reefs: An Ecosystem in Transition (ed. Z. Dubinsky and N. Stambler), pp. 215-229. Berlin: Springer.

Fine, M. and Loya, Y. (2002). Endolithic algae: an alternative source of photoassimilates during coral bleaching. Proc. R. Soc. Lond. B Biol. Sci. 269 1205-1210.

Frade, P. R., Bongaerts, P., Winkelhagen, A. J. S., Tonk, L. and Bak, R. P. M. (2008). In situ photobiology of corals over large depth ranges: a multivariate analysis on the roles of environment, host, and algal symbiont. Limnol. Oceanogr 53, 2711-2723.

Garren, M. and Azam, F. (2012). New directions in coral reef microbial ecology Environ. Microbiol. 14, 833-844.

Gattuso, J.-P., Pichon, M., Delesalle, B., Canon, C. and Frankignoulle, M. (1996). Carbon fluxes in coral reefs. I. Lagrangian measurement of community 
metabolism and resulting air-sea $\mathrm{CO}_{2}$ disequilibrium. Mar. Ecol. Prog. Ser. 145, 109-121.

Genin, A. (2004). Bio-physical coupling in the formation of zooplankton and fish aggregations over abrupt topographies. J. Mar. Syst. 50, 3-20.

Genin, A., Monismith, S. G., Reidenbach, M. A., Yahel, G. and Koseff, J. R (2009). Intense benthic grazing of phytoplankton in a coral reef. Limnol. Oceanogr. 54, 938-951.

Glynn, P. W. (1973). Ecology of a Caribbean coral reef. The Porites reef-flat biotope: Part II. Plankton community with evidence for depletion. Mar. Biol. 22 1-21.

Gnaiger, E. and Bitterlich, G. (1984). Proximate biochemical composition and caloric content calculated from elemental $\mathrm{CHN}$ analysis: a stoichiometric concept. Oecologia 62, 289-298.

Godinot, C., Houlbrèque, F., Grover, R. and Ferrier-Pagès, C. (2011). Coral uptake of inorganic phosphorus and nitrogen negatively affected by simultaneous changes in temperature and pH. PLOS ONE 6, e25024.

Grottoli, A. G. and Wellington, G. M. (1999). Effect of light and zooplankton on skeletal $\delta_{13} \mathrm{C}$ values in the eastern Pacific corals Pavona clavus and Pavona gigantea. Coral Reefs 18, 29-41.

Grottoli, A. G., Rodrigues, L. J. and Palardy, J. E. (2006). Heterotrophic plasticity and resilience in bleached corals. Nature 440, 1186-1189.

Grottoli, A. G., Warner, M. E., Levas, S. J., Aschaffenburg, M. D., Schoepf, V., McGinley, M., Baumann, J. and Matsui, Y. (2014). The cumulative impact of annual coral bleaching can turn some coral species winners into losers. Glob. Change Biol. 20, 3823-3833.

Grover, R., Maguer, J.-F., Allemand, D. and Ferrier-Pagès, C. (2008). Uptake of dissolved free amino acids by the scleractinian coral Stylophora pistillata. J. Exp. Biol. 211, 860-865

Hearn, C., Atkinson, M. and Falter, J. (2001). A physical derivation of nutrientuptake rates in coral reefs: effects of roughness and waves. Coral Reefs 20 347-356.

Heidelberg, K. B., Sebens, K. P. and Purcell, J. E. (2004). Composition and sources of near reef zooplankton on a Jamaican forereef along with implications for coral feeding. Coral Reefs 23, 263-276.

Heikoop, J. M., Dunn, J. J., Risk, M. J., Tomascik, T., Schwarcz, H. P., Sandeman, I. M. and Sammarco, P. W. (2000). $\delta^{15} \mathrm{~N}$ and $\delta^{13} \mathrm{C}$ of coral tissue show significant inter-reef variation. Coral Reefs 19, 189-193.

Hoogenboom, M., Rodolfo-Metalpa, R. and Ferrier-Pagès, C. (2010). Covariation between autotrophy and heterotrophy in the Mediterranean cora Cladocora caespitosa. J. Exp. Biol. 213, 2399-2409.

Houlbrèque, F. and Ferrier-Pagès, C. (2008). Heterotrophy in tropical scleractinian corals. Biol. Rev. 84, 1-17.

Houlbrèque, F., Tambutté, E., Richard, C. and Ferrier-Pagès, C. (2004) Importance of a micro-diet for scleractinian corals. Mar. Ecol. Prog. Ser. 282 151-160.

Hughes, A. D. and Grottoli, A. G. (2013). Heterotrophic compensation: a possible mechanism for resilience of coral reefs to global warming or a sign of prolonged stress? PLoS ONE 8, e81172.

Hughes, A. D., Grottoli, A. G., Pease, T. K. and Matsui, Y. (2010). Acquisition and assimilation of carbon in non-bleached and bleached corals. Mar. Ecol. Prog. Ser. 420, 91-101.

Jeffrey, S. W. and Humphrey, G. F. (1975). New spectrophotometric equations for determining chlorophylls $\mathrm{a}, \mathrm{b}, \mathrm{c}$ and $\mathrm{c} 2$ in higher plants, algae and natural phytoplankton. Biochem. Physiol. Pflanz. 167, 191-194.

Johannes, R. E., Coles, S. L. and Kuenzel, N. T. (1970). The role of zooplankton in the nutrition of some scleractinian corals. Limnol. Oceanogr. 15, 579-586

Johannes, R. E., Alberts, J., D'Elia, C., Kinzie, R. A., Pomeroy, L. R., Sottile, W., Wiebe, W., Marsh, J. A., Helfrich, P., Maragos, J. et al. (1972). The metabolism of some coral reef communities: a team study of nutrient and energy flux at Eniwetok. BioScience 22, 541-543.

Kushmaro, A. and Kramarsky-Winter, E. (2004). Bacteria as a source of cora nutrition. In Coral Health and Disease (ed. E. Rosenberg and Y. Loya), pp. 231-241. Berlin: Springer.

Land, L. S., Lang, J. C. and Smith, B. N. (1975). Preliminary observations on the carbon isotopic composition of some reef coral tissues and symbiotic zooxanthellae. Limnol. Oceanogr. 20, 283-287.

Leichter, J. J., Shellenbarger, G., Genovese, S. J. and Wing, S. R. (1998) Breaking internal waves on a Florida (USA) coral reef: a plankton pump at work? Mar. Ecol. Prog. Ser. 166, 83-97.

Lesser, M. P., Slattery, M., Stat, M., Ojimi, M., Gates, R. D. and Grottoli, A. (2010) Photoacclimatization by the coral Montastraea cavernosa in the mesophotic zone: light, food, and genetics. Ecology 91, 990-1003

Lester, N. P., Shuter, B. J. and Abrams, P. A. (2004). Interpreting the von Bertalanffy model of somatic growth in fishes: the cost of reproduction. Proc. R. Soc. Lond. B Biol. Sci. 271, 1625-1631.

Leuzinger, S., Anthony, K. R. N. and Willis, B. L. (2003). Reproductive energy investment in corals: scaling with module size. Oecologia 136 524-531.
Manzello, D. P. (2010). Coral growth with thermal stress and ocean acidification: lessons from the eastern tropical Pacific. Coral Reefs 29, 749-758.

Marsh, J. A.Jr. (1970). Primary productivity of reef-building calcareous red algae. Ecology 51, 255-263.

Marshall, P. A. (2000). Skeletal damage in reef corals: relating resistance to colony morphology. Mar. Ecol. Prog. Ser. 200, 177-189.

McCauley, E., Murdoch, W. W., Nisbet, R. M. and Gurney, W. S. C. (1990). The physiological ecology of Daphnia: development of a model of growth and reproduction. Ecology 71, 703-715.

McKinnon, A. D., Richardson, A. J., Burford, M. A. and Furnas, M. J. (2007) Chapter 6: Vulnerability of Great Barrier Reef plankton to climate change. In Climate Change and the Great Barrier Reef: A Vulnerability Assessment (ed. J. E. Johnson and P. A. Marshall), pp. 121-152. Townsville: Great Barrier Reef Marine Park Authority and Australian Greenhouse Office.

Mills, M. M., Lipschultz, F. and Sebens, K. P. (2004). Particulate matter ingestion and associated nitrogen uptake by four species of scleractinian corals. Coral Reefs 23, 311-323.

Muscatine, L. and Kaplan, I. R. (1994). Resource partitioning by reef corals as determined from stable isotope composition II. $\delta^{15} \mathrm{~N}$ of zooxanthellae and animal tissue versus depth. Pac. Sci. 48, 304-312.

Muscatine, L. and Porter, J. W. (1977). Reef corals: mutualistic symbioses adapted to nutrient-poor environments? BioScience 27, 454-460.

Muscatine, L., Porter, J. W. and Kaplan, I. R. (1989). Resource partitioning by reef corals as determined from stable isotope composition. I. $\delta^{13} \mathrm{C}$ of zooxanthellae and animal tissue vs depth. Mar. Biol. 100, 185-193.

Nahon, S., Richoux, N. B., Kolasinski, J., Desmalades, M., Pages, C. F., Lecellier, G., Planes, S. and Lecellier, V. B. (2013). Spatial and tempora variations in stable carbon $\left(\delta^{13} \mathrm{C}\right)$ and nitrogen $\left(\delta^{15} \mathrm{~N}\right)$ isotopic composition of symbiotic scleractinian corals. PLOS ONE 8, e81247.

Odum, H. P. and Odum, E. P. (1955). Trophic structure and productivity of a windward coral reef community on Eniwetok Atoll. Ecol. Monogr. 25 291-320

Palardy, J. E., Grottoli, A. G. and Matthews, K. A. (2005). Effects of upwelling depth, morphology and polyp size on feeding in three species of Panamanian corals. Mar. Ecol. Prog. Ser. 300, 79-89.

Palardy, J. E., Rodrigues, L. J. and Grottoli, A. G. (2008). The importance of zooplankton to the daily metabolic carbon requirements of healthy and bleached corals at two depths. J. Exp. Mar. Biol. Ecol. 367, 180-188.

Peterson, B. J. and Fry, B. (1987). Stable isotopes in ecosystem studies. Annu. Rev. Ecol. Syst. 18, 293-320.

Porter, J. W., Muscatine, L., Dubinsky, Z. and Falkowski, P. G. (1984). Primary production and photoadaptation in light-and shade-adapted colonies of the symbiotic coral, Stylophora pistillata. Proc. R. Soc. Lond. B Biol. Sci. 222 161-180.

R Core Development Team (2011). R: A language and environment for statistical computing. Vienna: R Foundation for Statistical Computing

Reynaud, S., Martinez, P., Houlbrèque, F., Billy, I., Allemand, D. and FerrierPagès, C. (2009). Effect of light and feeding on the nitrogen isotopic composition of a zooxanthellate coral: role of nitrogen recycling. Mar. Ecol. Prog. Ser. 392 $103-110$

Ribes, M., Coma, R., Atkinson, M. J. and Kinzie, R. A.III. (2003). Particle remova by coral reef communities: picoplankton is a major source of nitrogen. Mar. Ecol. Prog. Ser. 257, 13-23.

Richardson, A. J. (2008). In hot water: zooplankton and climate change. ICES J. Mar. Sci. 65, 279-295.

Roder, C., Fillinger, L., Jantzen, C., Schmidt, G. M., Khokiattiwong, S. and Richter, C. (2010). Trophic response of corals to large amplitude internal waves. Mar. Ecol. Prog. Ser. 412, 113-128.

Saffo, M. B. (1992). Invertebrates in endosymbiotic associations. Am. Zool. 32 557-565.

Schiller, C. and Herndl, G. J. (1989). Evidence of enhanced microbial activity in the interstitial space of branched corals: possible implications for coral metabolism. Coral Reefs 7, 179-184.

Sebens, K. P., Vandersall, K. S., Savina, L. A. and Graham, K. R. (1996) Zooplankton capture by two scleractinian corals, Madracis mirabilis and Montastrea cavernosa, in a field enclosure. Mar. Biol. 127, 303-317.

Shick, J. M., Ferrier-Pages, C., Grover, R. and Allemand, D. (2005). Effects of starvation, ammonium concentration, and photosynthesis on the UV-dependent accumulation of mycosporine-like amino acids (MAAs) in the coral Stylophora pistillata. Mar. Ecol. Prog. Ser. 295, 135-156.

Smith, S. V. (1981). The Houtman Abrolhos Islands: carbon metabolism of cora reefs at high altitude. Limnol. Oceanogr. 26, 612-621.

Swart, P. K. (1983). Carbon and oxygen isotope fractionation in scleractinian corals: a review. Earth Sci. Rev. 19, 51-80.

Tanaka, Y., Grottoli, A. G., Matsui, Y., Suzuki, A. and Sakai, K. (2015). Partitioning of nitrogen sources to algal endosymbionts of corals with long-term ${ }^{15} \mathrm{~N}$-labelling and a mixing model. Ecol. Mod. 309-310, 163-169.

Titlyanov, E. A., Titlyanova, T. V., Yamazoto, K. and van Woesik, R. (2001) Photo-acclimation dynamics of the coral Stylophora pistillata to low and extremely low light. J. Exp. Mar. Biol. Ecol. 263, 211-225. 
Tremblay, P., Peirano, A. and Ferrier-Pagès, C. (2011). Heterotrophy in the Mediterranean symbiotic coral Cladocora caespitosa: comparison with two other scleractinian species. Mar. Ecol. Prog. Ser. 422, 165-177.

Tremblay, P., Grover, R., Maguer, J. F., Hoogenboom, M. and Ferrier-Pagès, C. (2014). Carbon translocation from symbiont to host depends on irradiance and food availability in the tropical coral Stylophora pistillata. Coral Reefs 33 , $1-13$.

Tremblay, P., Maguer, J. F., Grover, R. and Ferrier-Pagès, C. (2015). Trophic dynamics of scleractinian corals: stable isotope evidence. J. Exp. Biol. 218, 1223-1234.
Wijgerde, T., Diantari, R., Lewaru, M. W., Verreth, J. A. J. and Osinga, R. (2011). Extracoelenteric zooplankton feeding is a key mechanism of nutrient acquisition for the scleractinian coral Galaxea fascicularis. J. Exp. Biol. 214, 3351-3357.

Yahel, R., Yahel, G., Berman, T., Jaffe, J. S. and Genin, A. (2005). Diel pattern with abrupt crepuscular changes of zooplankton over a coral reef. Limnol. Oceanogr. 50, 930-944.

Yellowlees, D., Rees, T. A. V. and Leggatt, W. (2008). Metabolic interactions between algal symbionts and invertebrate hosts. Plant Cell Environ. 31, 679-694. 